\title{
Fatal infantile cytochrome C oxidase deficiency
}

INSERM

\section{Source}

INSERM. (1999). Orphanet: an online rare disease and orphan drug data base. Fatal infantile cytochrome Coxidase deficiency. ORPHA:1561

Fatal infantile cytochrome $\mathrm{C}$ oxidase deficiency is a very rare mitochondrial disease characterized clinically by cardioencephalomyopathy resulting in death in infancy. 